\title{
Quantitative analysis of bone morphogenetic protein 15 (BMP15) and growth differentiation factor 9 (GDF9) gene expression in calf and adult bovine ovaries
}

\author{
Misa Hosoe ${ }^{1 *}$, Kanako Kaneyama $^{1,2}$, Koichi Ushizawa $^{1}$, Ken-go Hayashi ${ }^{1}$, Toru Takahashi ${ }^{1}$
}

\begin{abstract}
Background: It has been reported that calf oocytes are less developmentally competent than oocytes obtained from adult cows. Bone morphogenetic protein 15 (BMP15) and growth and differentiation factor 9 (GDF9) play critical roles in folliculogenesis, follicular development and ovulation in mammalian ovaries. In the present study, we attempted to compare the expression patterns of BMP15 and GDF9 in the cells of calf and cow ovaries to determine a relationship between the level of these genes and the low developmental competence of calf oocytes.
\end{abstract}

Methods: Bovine tissues were collected from 9-11 months-old calves and from 4-6 years-old cows. We characterized the gene expression of BMP15 and GDF9 in calf and adult bovine oocytes and cumulus cells using quantitative real-time reverse transcriptase polymerase chain reaction (QPCR) and in situ hybridization. Immunohistochemical analysis was also performed.

Results: The expression of BMP15 and GDF9 in cumulus cells of adult ovaries was significantly higher than that in calf ovaries, as revealed by QPCR. GDF9 expression in the oocytes of calf ovaries was significantly higher than in those of the adult ovaries. In contrast, BMP15 expression in the oocytes of calf and adult ovaries was not significantly different. The localization of gene expression and protein were ascertained by histochemistry.

Conclusions: Our result showed for the first time BMP15 and GDF9 expression in bovine cumulus cells. BMP15 and GDF9 mRNA expression in oocytes and cumulus cells was different in calves and cows.

\section{Background}

Growth and differentiation factor 9 (GDF9) and GDF9B, also known as BMP15, are members of the TGF $\beta$ superfamily [1-6]. In rodent species, BMP15 and GDF9 play a crucial role in ovarian follicular development. The two factors are thought to affect granulosa cell proliferation independently or synergistically $[2,4,7]$ and to regulate cumulus cell function in the periovulatory period [8-10]. BMP15 inhibits FSH-induced granulosa cell differentiation through down-regulation of FSH receptor (FSHR) expression in rat granulosa cells [11]. GDF9 homozygous

\footnotetext{
* Correspondence: hosoe@affrc.go.jp

'Reproductive Biology Research Unit, Division of Animal Sciences, National Institute of Agrobiological Sciences, 2-1-2 Kannondai, Tsukuba, Ibaraki 3058602, Japan

Full list of author information is available at the end of the article
}

knockout (GDF9-/-) female mice are sterile due to the abolishment of folliculogenesis beyond the primary follicle stage $[12,13]$. However, such a dramatic effect is not observed in BMP15 homozygous knockout (BMP15-/-) mice [14]. The functionality of BMP15 and GDF9 in ruminants was mainly reported in sheep. Some sheep breeds, having mutation in the BMP15 and GDF9 signaling systems, have been established as valuable genetic resources for sheep farming because of their prolificacy phenotype. These breeds have a higher ovulation quota and produce more offspring than other conventional breeds [15-17].

It was reported that BMP15 and GDF9 expressed only in oocytes in rodents, but expressed in cumulus and mural granulosa cells as well as in oocytes in goats and 
pigs $[1,3,5]$. In bovine oocytes, although it has been reported that BMP15 and GDF9 mRNAs were expressed from respective primary and primordial follicles, and that the expression lasted to the 8-cell stage after fertilization [18], there is not enough information about the detailed expression profiles of BMP15 and GDF9. Recently, Hussein et al. reported that the addition of exogenous GDF9 and BMP15 to maturing cumulusoocyte complexes (COCs) dramatically increased the yield of blastocysts [19]. They also reported that the addition of GDF9 and/or BMP15 antagonist to maturing COCs significantly decreased blastocyst yields, compared to untreated COCs [19].

In the bovine ovary, antral follicles appeared for the first time in the fetuses with a head-rear length of 70-80 cm (7-8 months pregnant) [20]. The use of newborns and prepubertal calves as oocyte donors for IVP shortens the interval between generations and prolongs the reproduction period. However, it is known that prepubertal calf oocytes are less developmentally competent than oocytes obtained from cows. Although the rates of fertilization and cleavage in prepubertal calf oocytes compared favorably with those in cow oocytes, their capacity to develop to the blastocyst stage is relatively lower [21-23]. It would seem that embryos from calf oocytes are less capable of establishing pregnancies [24]. Calf oocytes were found to be more sensitive to freezing injury than cow oocytes [25]. Calf oocytes showed a delay in organelle migration, mainly cortical granules, following in vitro maturation, as well as abnormal chromatin and microtubule configurations [26]. It is an important to analyze the genes that are related to the development of calf oocytes.

In this study, we characterized the gene expression of BMP15 and GDF9 in calf and adult bovine ovaries using quantitative real-time reverse transcriptase polymerase chain reaction (QPCR) and in situ hybridization. In addition, we also characterized the gene expression of FSHR in cumulus cells of calf and adult ovaries.

\section{Methods}

\section{Animals and tissues}

Protocols for the use of animals were approved by the Animal Care Committee of the National Institute of Agrobiological Sciences and the National Institute of Livestock and Grassland Science, Japan. Bovine tissues were collected from 9-11 months-old calves and from 4-6 years-old cows, born, grown and slaughtered at the National Institute of Livestock and Grassland Science less than $10 \mathrm{~min}$ after slaughtering. Tissues intended for PCR experiments were snap-frozen in liquid nitrogen and stored at $-80^{\circ} \mathrm{C}$. Ovaries were brought to the laboratory in PBS at $4^{\circ} \mathrm{C}$ and COCs were aspirated, separated into oocytes and cumulus cells and snap-frozen less than 60 min after slaughtering. Ovaries intended for histological studies were fixed with $10 \%$ formaldehyde PBS, $\mathrm{pH} 7.4$ less than 10 min after slaughtering, and subsequently dehydrated, embedded in paraffin wax, and stored at $4^{\circ} \mathrm{C}$.

Aspirated COCs from follicles 2-5 $\mathrm{mm}$ in diameter were classified according to a previous report [27]. Briefly, class A COCs have a thick cumulus layer; class $B$ COCs have a thin cumulus layer, class $C$ are naked oocytes, and COCs of class D have expanded cumulus cells. Oocytes, cumulus cells and mural granulosa cells from class A and B COCs were used as materials for reverse transcriptase polymerase chain reaction (RT-PCR). For RT-PCR, COCs were separated from the ovaries of calves ( $\mathrm{n}=4$ animals) and cows $(\mathrm{n}=4$ animals). For in situ hybridization, ovaries were recovered from calves ( $\mathrm{n}=3$ animals) and cows ( $\mathrm{n}=3$ animals).

\section{RT-PCR}

Liver, kidney, heart, spleen, lung, ovary and pituitary tissues were collected from the same cows. Oocytes with zona pellucida and cumulus cells in COCs were separated by vortexing and/or repeated aspiration with a narrow-bore Pasteur pipette. After collection, all cells were treated with ISOGEN (Nippon Gene, Toyama, Japan) and stored at $-80^{\circ} \mathrm{C}$ until RNA extraction.

Total RNA extraction and reverse transcription were performed as previously reported [28]. RT-PCR was performed using two sets of primers, BMP15 (5'CAAGCAGGCAGTATTGCATCTGAA-3' and 5'TCACCTACATGTGCAGGACTGGGC-3'), and GDF9 (5'- AGAAGCTGCTGAGGGTGTAAGATT-3' and 5'AAGCAATTGAGCCATCAGGC-3') that generated 377- and 401-bp fragments, respectively. The GenBank accession numbers of bovine BMP15 and GDF9 for PCR analysis are AY572412 and AB058416. All primers were commercially synthesized (Tsukuba Oligo Service, Ibaraki, Japan). The program comprised an initial denaturation step at $95^{\circ} \mathrm{C}$ for $30 \mathrm{sec}$, annealing at $58^{\circ} \mathrm{C}$ for $30 \mathrm{sec}$, and extension at $72^{\circ} \mathrm{C}$ for $1 \mathrm{~min}$. Each PCR was performed for 30 cycles for each sample. PCR products were analyzed using agarose gel electrophoresis and visualized with Gel Star Nucleic Acid Gel Stain (Cambrex Bio Science Rockland, Inc, USA). Bovine glyceraldehyde-3-phosphate dehydrogenase (GAPDH) was used as a control for PCR. To clarify the contamination of oocytes, PCR analysis of germ cell markers $V A S A$ and ZAR1 was performed in a cDNA template of cumulus and mural granulosa cells. Primer sequences of VASA (5'- CAATTCGACAAATAGTACAAGG-3' and 5'- CAAGAACTGGGCACTTTCC-3') and ZAR1 (5'- GGAGCTGGGCAAGGAGCG-3' and 5' - TTTGAAGCTGAAAGTGCTGTCAC-3') were used from a previous report [18]. 


\section{QPCR}

QPCR analyses for the gene expression of BMP15, GDF9 and FSHR in ovarian cells were carried out by the SYBR Green assay as previously reported [29,30]. The thermal cycling conditions included initial sample incubation at $50^{\circ} \mathrm{C}$ for $2 \mathrm{~min}$ and at $95^{\circ} \mathrm{C}$ for $10 \mathrm{~min}$, followed by 40 cycles at $95^{\circ} \mathrm{C}$ for $15 \mathrm{sec}$ and at $60^{\circ} \mathrm{C}$ for $1 \mathrm{~min}$. The cycle threshold values $\left(\mathrm{C}_{\mathrm{T}}\right)$ indicated the quantity of the target gene in each sample, and the sequence of the target gene was determined in real time using an Mx3000P QPCR system (Stratagene, La Jolla, CA, USA). Standard curves were generated for each gene by serial dilution of pGEM-cloning vectors containing BMP15, GDF9, and GAPDH cDNAs to quantify the amplified products. Real-time RT-PCR was performed using primers (BMP15: 5'-ATCATGCCATCATCCAGAACC-3' and 5'- TAAGGGACACAGGAAGGCTGA = 3', GDF9: 5' - AGCGCCCTCACT GCTTCTATAT-3' and 5'- TTCCTTTTAGGGTGGAGGGAA-3', FSHR: 5'-AATCTACCTGCTGCTCATAGCCTC-3' and 5'- TTTGCCAGTCGATGGCAT AG-3') that generated 72-, 80- and 76-bp fragments. The GenBank accession number of bovine FSHR is NM174061.

\section{In situ hybridization}

Digoxigenin (DIG)-labeled bovine BMP15 and GDF9 sense- and antisense-complementary RNA probes were synthesized as described in a previous study [31]. The PCR products of BMP15 and GDF9 in the previous RTPCR section were used as the templates for the RNA probe. Embedded ovaries were sectioned into $7-\mu \mathrm{m}$ thick slices. In situ hybridization was performed using an automated processing machine (Ventana HX System Discovery) with RiboMapKit, BlueMapKit, and AmpMapKit (Ventana, Tucson, AZ, USA) according to the manufacturer's instructions. The sections were fixed and treated with protease after deparaffinization. DIG-labeled probes diluted in RiboHybe hybridization solution (Ventana) were added to each section and hybridized at $61^{\circ} \mathrm{C}$ for $6 \mathrm{hr}$. Following hybridization, the sections were washed three times in RiboWash (Ventana) at $65^{\circ} \mathrm{C}$ for $6 \mathrm{~min}$ and post-fixed in RiboFix (Ventana) at $37^{\circ} \mathrm{C}$ for $10 \mathrm{~min}$. To detect the hybridization signals, the sections were incubated with polyclonal rabbit-anti-DIG/HRP conjugate (Dako Cytomation, Glostrup, Denmark) at $37^{\circ} \mathrm{C}$ for $30 \mathrm{~min}$. AmpMapKit (Ventana) was used to sensitize the hybridization signals. BlueMapKit (Ventana) with NBT/BCIP was used to color the hybridized signals blue. Counterstaining was performed with Nuclear Fast Red (Ventana). After preparation, the sections were mounted and observed with a Nikon ECLIPSE E800 photomicroscope (Nikon, Tokyo, Japan).

\section{Production of bovine BMP15 and GDF9 antibody}

Recombinant BMP15 and GDF9 were expressed by using a cell-free system (Rapid Translation Systems, Roche Diagnostics, Basel, Switzerland). Bovine cDNAs encoding the mature protein regions of BMP15 and GDF9 were cloned by RT-PCR with high-fidelity DNA polymerase ( $P f u$ polymerase, Stratagene, La Jolla, CA, US). Amino termini of mature protein regions were predicted based on the consensus motif R-X-X-R as a target of subtilisin-like proteases.

Cloned sequences were subcloned to the pIVEX 2.4d expression vector (Roche). Protein expression was carried out using E.coli lysate reagent (RTS Proteomaster HY Kit, Roche) according to the manufacturer's instructions. The RTS reaction chamber used in the present study contained $1 \mathrm{ml}$ of reaction mixture and $11 \mathrm{ml}$ of feeding solution. After $24 \mathrm{hr}$ of incubation, $1 \mathrm{ml}$ of reaction mixture was harvested from the chamber, solubilized with $4 \mathrm{ml}$ of $8 \mathrm{M}$ urea solution, and centrifuged at $22000 \times \mathrm{g}$ for $10 \mathrm{~min}$ at $4^{\circ} \mathrm{C}$ to collect the supernatant. Recombinant proteins were purified from the supernatant using a nickel sepharose affinity gel (GE Healthcare, Buckinghamshire, UK) in the presence of $6 \mathrm{M}$ urea, based on the chromatography. Anti-BMP15 and GDF9 antisera were generated in rabbits. The rabbits were bled prior to immunization to obtain preimmunoserum. They were initially inoculated with $300 \mu \mathrm{g}$ of the antigen in Freund's complete adjuvant. Three weeks after initial immunization, the rabbits were further inoculated with $150 \mu \mathrm{g}$ of the antigen in Freund's incomplete adjuvant. Animals were given three booster injections at two-week intervals. The titer of antiserum was monitored by ELISA. Two weeks after the third booster injection, animals were exsanguinated to collect antiserum.

\section{Western blot analysis}

To confirm the immunoreactive property of custom anti-BMP15 and GDF9 antisera, recombinant BMP15 and GDF9 were used for Western Blot analysis. Samples (100ng each) were separated by sodium dodecyl sulfatepolyacrylamide electrophoresis and electrophoretically transferred onto a polyvinylidene difluoride membrane [32]. Western blotting was performed using the method of Towbin et al. in Tris-buffered saline (TBS) [33]. The membrane was blocked in $10 \%$ skim milk overnight, incubated with either anti-BMP15 or -GDF9 antisera in $1 \%$ skim milk in TBS for $1 \mathrm{hr}$ at room temperature and then washed with TBS containing $0.05 \%$ Tween 20 (TBST). It was then incubated with anti-rabbit IgG conjugated with alkaline phosphatase (Sigma, diluted 1:3000) for $1 \mathrm{hr}$ at room temperature and then washed with TBST. Immunopositive bands were detected using AP substrate kit (BioRad, Hercules, CA, USA). 


\section{Immunohistochemistry}

Immunohistochemistry was performed using an automated processing machine with the RiboMapKit and DABMapKit reagents (Ventana). The sections were incubated with antiserum or pre-immunoserum at a dilution of 1:100 in Ab Diluent (Ventana) for $2 \mathrm{hr}$. For the first antibody, not only custom antibody, but also commercial antibody; anti-humanBMP15 antibody (Abjent, CA, US) and anti-mouse GDF9 antibody (Santa Cruz CA, USA) were used. The sections were then washed and incubated with anti-rabbit IgG-Biotin (Sigma) for $1 \mathrm{hr}$. Immunoreactive signals were detected using streptavidin-HRP and diaminobenzidine (DABMapKit, Ventana). After preparation, the sections were observed with a Nikon ECLIPSE E800 photomicroscope (Nikon, Tokyo, Japan).

\section{Statistical analysis}

Rates of antral follicles and COCs were analyzed by a Chi-square test. A $t$-test was used to compare the results of QPCR quantification. The experiments were carried out in at least three replicates. The results quantifying copy numbers of BMP15 and GDF9 mRNA are expressed as the mean of the ratio of BMP15 or GDF9 to $G A P D H$. Statistical significance was set at $P<0.05$.

\section{Results}

BMP15 transcripts were detected in ovarian tissues, but were not detected in any other tissues examined by RT-PCR. In contrast, GDF9 transcripts were detected not only in the ovarian tissues but also in the pituitary tissues, but were not detected in the liver, kidney, heart, spleen or lung tissues (Figure 1). In both oocytes and cumulus cells collected from adult cows, BMP15 and GDF9 transcripts were detected (Figure 2).

The amount of class A and B COCs collected from calf ovaries $(59.3 \%, \mathrm{n}=59)$ was significant less than that from adult ovaries $(77.0 \%, \mathrm{n}=87)(\mathrm{P}<0.05)$. The germ cell marker $V A S A$ and $Z A R 1$ transcripts were detected

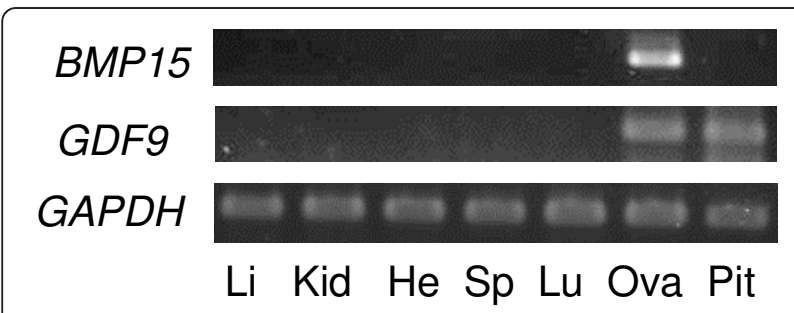

Figure 1 mRNA expression of BMP15 and GDF9 in bovine tissues by RT-PCR. Total RNAs were extracted from liver (Li), kidney (Kid), heart (He), spleen (Sp), lung, (Lu) ovarian (Ov), and pituitary (Pit) tissues. Signal produced by BMP15 primers (377-bp) was only detected in the ovarian tissues. Signals produced by GDF9 primers (401-bp) were detected in the ovarian and pituitary tissues.

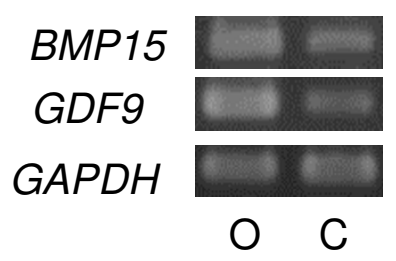

Figure 2 mRNA expression of BMP15 and GDF9 in follicles by RT-PCR. Total RNAs were extracted from oocytes $(\mathrm{O})$ and cumulus cells (C). Signal produced by BMP15 primers (377-bp) and GDF9 primers (401-bp) were detected in the oocytes and cumulus cells.

in the cDNA template of the oocytes, but not in the cDNA template of cumulus cells (data not shown). Therefore, it was confirmed that the cDNA template of cumulus cells were not contaminated with the cDNA template of oocytes. QPCR detected significantly higher expression of BMP15 and GDF9 in cumulus cells of adult ovaries than in calf ovaries (Figure 3). GDF9 expression in the oocytes of calf ovaries was significantly higher than in adult ovaries. In contrast, BMP15 expression in the oocytes of calf and adult ovaries was not significantly different. These results were also ascertained by in situ hybridization (Figure 4). RNA probes, DIGlabeled BMP15 and GDF9 anti-sense RNAs specifically detected the mRNA transcript in calf and adult ovaries (Figure 3A, C, E and 3G), while the sense probe detected no significant signal (Figure $3 \mathrm{~B}, \mathrm{D}, \mathrm{F}$ and $3 \mathrm{H}$ ). In the antral follicles of calf ovaries, BMP15 and GDF9 mRNAs were strongly detected in the oocytes (Figure $3 \mathrm{~A}$ and $3 \mathrm{E}$ ) and were weakly detected in the cumulus cells. In the antral follicles of adult ovaries, BMP15 and GDF9 mRNAs were detected in the cumulus cells as well as in the oocytes of antral follicles (Figure $3 \mathrm{C}$ and 3G). GDF9 mRNA was also detected in some mural granulosa cells and in a few theca cells (Figure 3G). The BMP15 and GDF9 recombinant proteins with 6xHis tag were produced by using a cell free system as approximately 15 and $18 \mathrm{kDa}$. Subsequently generated antisera against either BMP15 or GDF9 reacted with immunized antigens in Western blot analysis (Figure 5). BMP15 and GDF9 localization was determined by immunohistochemistry using both custom and commercial antisera in calf and cow ovaries (Figure 6). Immunopositive signals of BMP15 and GDF9 were detected in the oocytes and cumulus cells of follicles in both calf (Figure 6A and $6 \mathrm{C}$ ) and cow (Figure 6B and 6D) ovaries. There was no difference in the localization of immunopositive signals in sections incubated with either commercial or in house antisera. The localization of BMP15 and GDF9 protein coincided with that of BMP15 and GDF9 mRNA. In contrast, the additions of pre-immuno sera, instead of BMP15 and GDF9 antisera, made no immunoreactive signals (Figure 6E and 6F) in the follicles. 


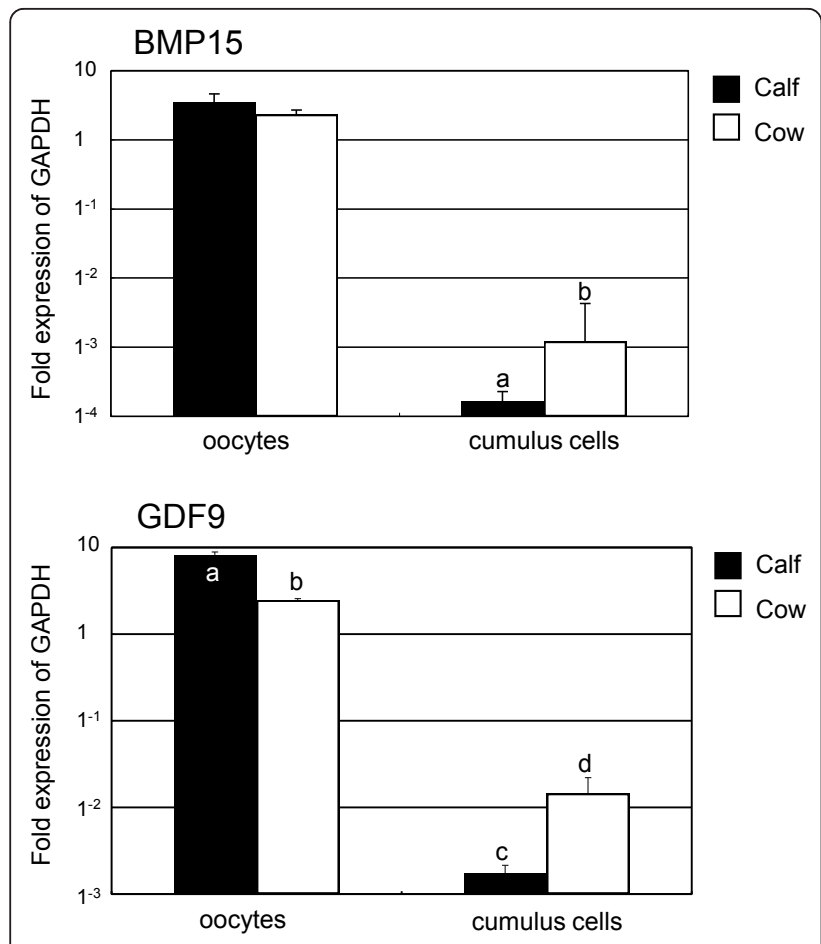

Figure 3 QPCR analysis of BMP15 and GDF9 mRNA in the cells of ovaries derived from calves or cows. Total RNA was extracted from oocytes, cumulus cells and mural granulosa cells. The expression of these mRNAs was normalized to the expression of GAPDH measured in the same RNA preparation. Results of three independent experiments are summarized and expressed as the mean \pm SEM. Different letters above the bars indicate significant differences $(P<0.05)$
QPCR revealed that the intensity of FSHR in the cumulus cells of calf and adult ovaries was not significantly different (Figure 7).

\section{Discussion}

In this research, our data showed the existence of bovine BMP15 and GDF9 mRNA and protein expression, not only in the oocytes but also in follicular somatic cells. Also we showed new differences in mRNA expression patterns of BMP15 and GDF9 in oocytes and cumulus cells between calf and cow ovaries.

There was no difference in the amount of intra oocyte BMP15 mRNA between calf and cow, and was smaller in calf cumulus cells than in cow cumulus cells. Thus, it is predicted that the amount of BMP15 in follicles is greater in cows than in calves. The lower developmental competence of calf oocytes may be partially explained by a deficiency of BMP15 in cumulus cells. It was showed the possibility which additional BMP15 in IVM improve the developmental competence of calf oocytes.

GDF9 mRNA expression in cumulus cells was detected by QPCR and in situ hybridization even though at a low level. In previous reports, GDF9 mRNA expression was detected in oocytes, but not in bovine cumulus and mural granulosa cells by RT-PCR [34] or by in situ hybridization [35]. Our results differ from these previous reports. This difference in expression may be related to the status of follicle atresia or to the estrous cycle. The amount of GDF9 gene expression was smaller in calf cumulus cells than in cow cumulus cells, same as the

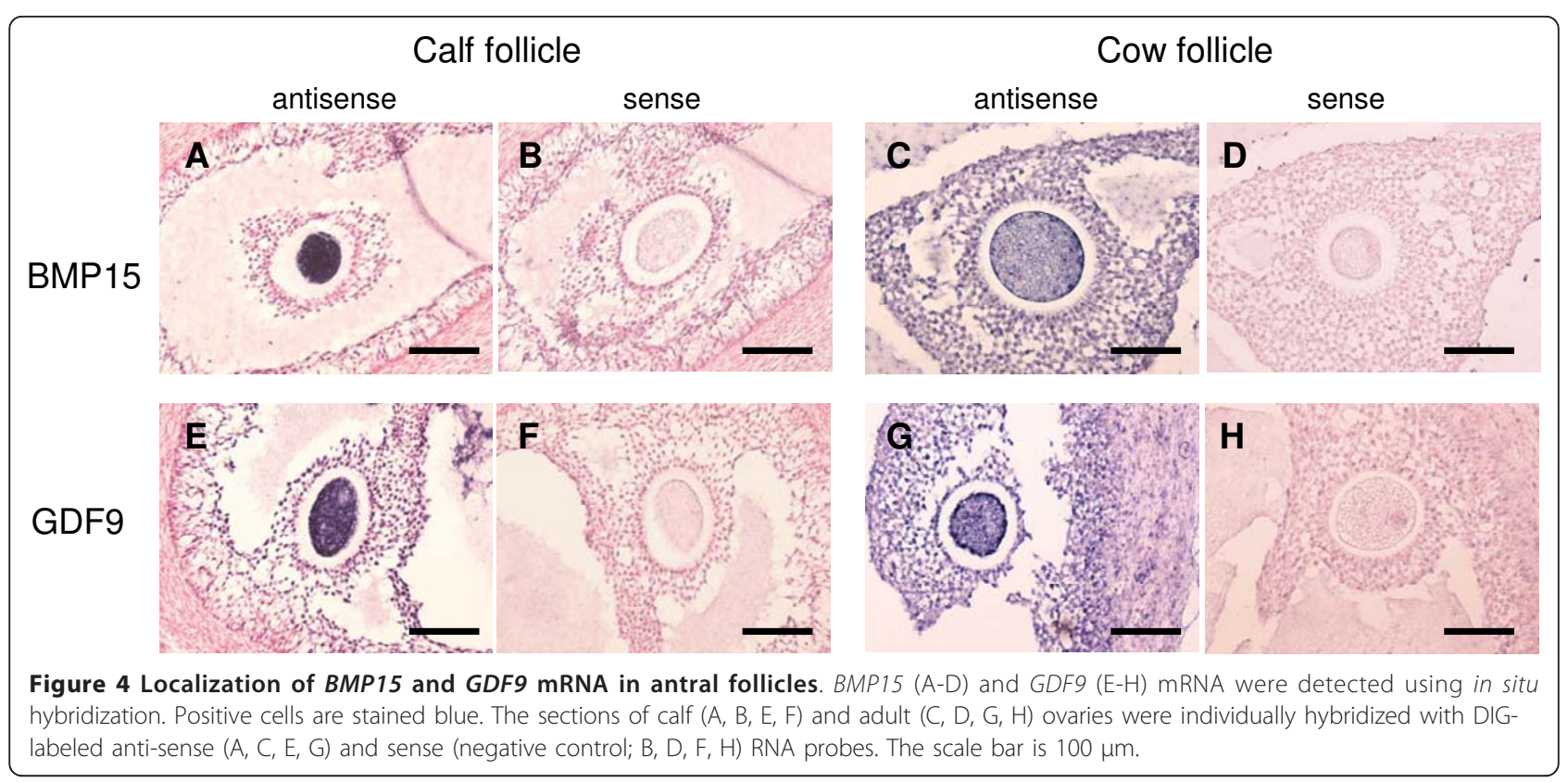




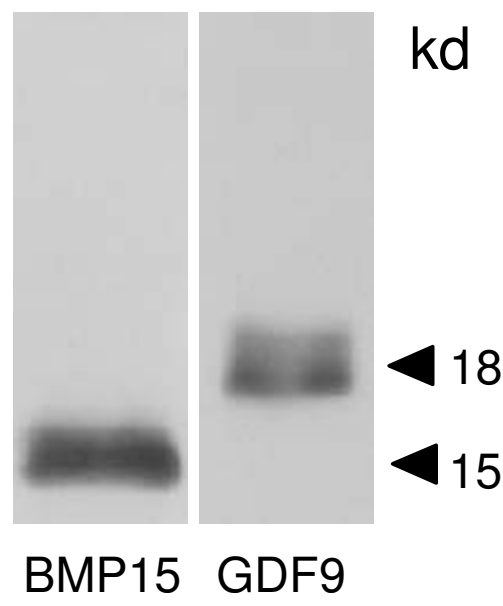

Figure 5 Western blot analysis of recombinant His-tag fusion bBMP15 and GDF9 protein. Recombinant proteins were loaded onto separate lanes and separated by SDS-PAGE. Specific proteins were detected by using custom BMP15 and GDF9 antibody.

amount of BMP15. The two factors are thought to have synergistic effect to proliferate or regulate granulosa cells $[2,7,8]$. There is a possibility that the smaller expression of both BMP15 and GDF9 in cumulus cells of calves affect function of granulosa cells. The amount of GDF9 gene expression was greater in calf oocytes, than in cow oocytes, unlike in the cumulus cells. It is required further study to clarify relationship between the low developmental competence of calves and GDF9.

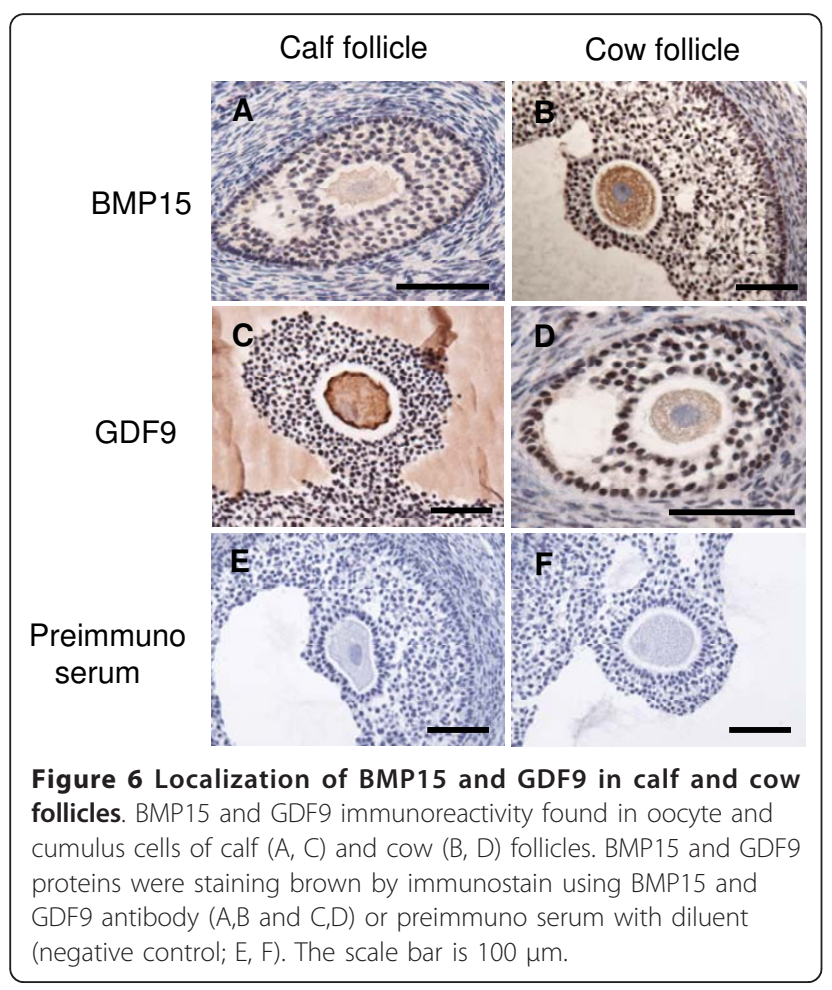

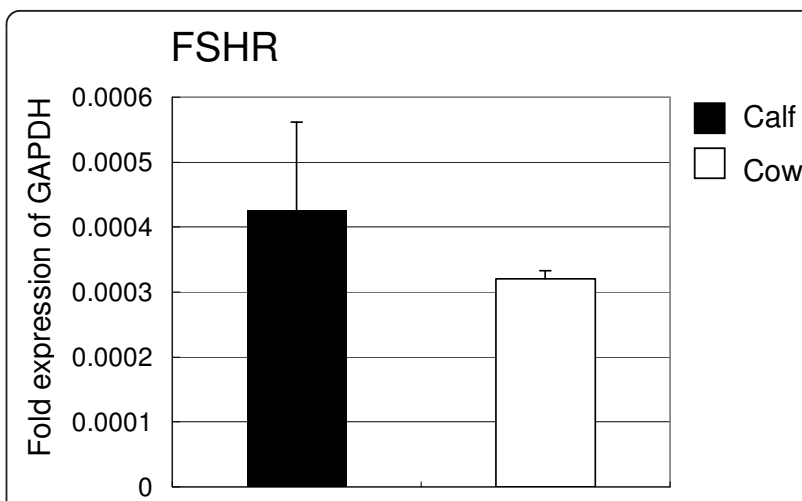

Figure 7 QPCR analysis of FSHR mRNA in the cells of ovaries derived from calves or cows. Total RNA was extracted from cumulus cells and mural granulosa cells. The expression of these mRNAs was normalized to the expression of GAPDH measured in the same RNA preparation. Results of three independent experiments are summarized and expressed as the mean \pm SEM. Different letters above the bars indicate significant differences $(P<0.05)$.

BMP15 inhibits FSH-induced granulosa cell differentiation through down-regulation of FSH receptor (FSHR) expression in rat granulosa cells [11]. In our results, although QPCR revealed that the intensity of BMP15 expression in the cumulus cells of adult ovaries was significantly higher than that of calf ovaries, the intensity of FSHR in cumulus cells of calf and adult ovaries was not significantly different. In mutant sheep, the FSHR binding assay showed no difference in FSH responsiveness in granulosa cells between animals heterozygous for BMP15 mutation, whose phenotype is a higher ovulation rate, and wild-type [36]. Whether ruminant BMP15 inhibits FSHR gene expression and FSHR activity needs further investigation. Previously, we reported that FSHR mRNA expression was greater in bovine largest $(10.7+/-0.7 \mathrm{~mm})$ and healthy follicles than in second-largest $(7.8+/-0.2 \mathrm{~mm})$ and atretic follicles [30]. However, our results could not clarify the relationship between the developmental competence of oocytes and FSHR mRNA expression in the cumulus cells.

When comparing rodents with an incomplete estrus cycle (mice, rats) to other animals with a complete estrous cycle (humans, goats pigs and cows), GDF9 and BMP15 appear in different tissues. In rodents, BMP15 and GDF9 expressed exclusively in oocytes $[1,13,37,38]$. However, in other species, including humans [39], goats [5], pigs [3] and cows (this study), BMP15 and GDF9 were expressed in cumulus cells as well as in oocytes. BMP15 and GDF9 have somewhat different roles between rodents and ruminants: for example, in the phenotypes of null mutations $[12,14,16]$ and the ability to regulate ovulation rates $[12,14,16,40-42]$. It was speculated that these species-specific functional differences between monoovulatory human and sheep and 
polyovulatory mouse were attributable to the timing of processing of the BMP15 proprotein into a functionally mature BMP15 [43]. Although the biological significance of BMP15 expression in follicular somatic cells has not been fully elucidated, previous reports and the results of the present study indicate the possibility that BMP15 in somatic cells as well as in oocytes may regulate the selection of follicle and/or ovulation in species with a complete estrus cycle.

Differences in BMP15 expression between rodents and cows were also detected in the pituitary. In mice, $B M P 15$ is expressed in the pituitary $[44,45]$. It was hypothesized that BMP15 could play a physiological role in the monotropic rise of FSH secretion by the pituitary during the estrous and menstrual cycle [45]. However, BMP15 was not expressed in the bovine pituitary (Figure 1). In contrast, GDF9 was detected in rodents and human pituitary [46]. Our results also revealed that GDF9 mRNA was expressed in the bovine pituitary (Figure 1). The physiological role of bovine GDF9 in the pituitary remains to be determined.

In conclusion, this study demonstrated, for the first time, that the intensity of expression of transcripts encoding GDF9 and BMP15 differed between calf and adult ovaries. Our results suggest that the lower developmental competence in calf oocytes is associated with immature expression of BMP15/GDF9 in an intrafollicular environment.

\section{Conclusions}

We characterized the gene expression of BMP15 and GDF9 in calf and adult bovine oocytes and cumulus cells using QPCR and in situ hybridization. The expression of BMP15 and GDF9 in cumulus cells of adult ovaries was significantly higher than that in calf ovaries. GDF9 expression in the oocytes of calf ovaries was significantly higher than that of the adult ovaries. The localization of gene and protein expression was ascertained by in situ hybridization and immunohistochemintry. We suggest the possibility that the lower developmental competence of calf oocytes when compared to that of cow oocytes, is related to the different expression of $B M P 15$ and/or GDF9 in oocyte and cumulus cells.

\footnotetext{
Acknowledgements

We would like to thank members of technical support section 1 of the National Institute of Livestock and Grassland Science, Japan, for animal treatment. We appreciate the review of this manuscript prior to submission by SciRevision.

\section{Author details}

${ }^{1}$ Reproductive Biology Research Unit, Division of Animal Sciences, National Institute of Agrobiological Sciences, 2-1-2 Kannondai, Tsukuba, Ibaraki 3058602, Japan. ${ }^{2}$ Department of Technology, National Livestock Breeding Center, 1 Odakurahara, Odakura, Nishigo, Fukushima 961-8511, Japan.
}

\section{Authors' contributions}

$\mathrm{MH}$ participated in the design of the study, collected the materials, carried out all experiments and drafted the manuscript. KK, KU, KGH and TT collected the materials and helped to carry out RT-PCR, QPCR and in situ hybridyzation. $\mathrm{KU}$ and $\Pi \mathrm{T}$ also helped to draft the manuscript. All authors read and approved the final manuscript.

\section{Competing interests}

The authors declare that they have no competing interests.

Received: 27 October 2010 Accepted: 15 March 2011 Published: 15 March 2011

\section{References}

1. Otsuka F, Yao Z, Lee TH, Yamamoto S, Erickson GF, Shimasaki S: Bone morphogenetic protein-15. J Biol Chem 2000, 275:39523-39528.

2. Juengel JL, Hudson NL, Heath DA, Smith P, Reader KL, Lawrence SB, O'Connell AR, Laitinen MPE, Cranfield M, Groome NP, Ritvos O, McNatty KP: Growth differentiation factor 9 and bone morphogenetic protein 15 are essential for ovarian follicular development in sheep. Biol Reprod 2002, 67:1777-1789.

3. Prochazka R, Nemcova L, Nagyova E, Kanka J: Expression of growth differentiation factor 9 messenger RNA in porcine growing and preovulatory ovarian follicles. Biol Reprod 2004, 71:1290-1295.

4. McGrath SA, Esquela AF, Lee SJ: Oocyte-specific expression of growth/ differentiation factor-9. Mol Endocrinol 1995, 9:131-136.

5. Silva JRV, Van Den Hurk R, Van Tol HTA, Roelen BAJ, Figueiredo JR: Expression of growth differentiation factor 9 (GDF9), and bone morphogenetic protein 15 (BMP15), and BMP receptors in the ovaries of goats. Mol Reprod Dev 2005, 70:11-19.

6. Aaltonen J, Laitinen MP, Vuojolainen K, Jaatinen R, Horelli-Kuitunen N, Seppa L, Louhio H, Tuuri T, Sjoberg J, Butzow R, Hovata O, Dale L, Ritvos O: Human growth differentiation factor 9 (GDF9) and its novel homolog GDF9B are expressed in oocytes during early folliculogenesis. J Clin Endocrinol Metab 1999, 84:2744-2750.

7. Chang $\mathrm{H}$, Brown CW, Matzuk MM: Genetic analysis of the mammalian transforming growth factor- $\beta$ superfamily. Endocrine Rev 2002, 23:787-823.

8. Su YQ, Wu X, O'Brien ML, Pendola FL, Denegre JN, Matzuk MM, Eppig JJ: Synergistic roles of the oocyte-cumulus cell complex in mice: genetic evidence for an oocyte-granulosa cell regulatory loop. Dev Biol 2004, 276:64-73.

9. Gui LM, Joice IM: RNAi evidence that GDF9 mediates oocyte regulation of cumulus expansion in mice. Biol Reprod 2005, 72:195-199.

10. Pangus SA, Matzuk MM: The art and artifact of GDF9 activity: cumulus expansion and the cumulus expansion-enabling factor. Biol Reprod 2005, 73:582-585

11. Otsuka F, Yamamoto S, Erickson GF, Shimasaki S: Bone morphogenetic protein-15 inhibits follicle-stimulating hormone (FSH) action by suppressing FSH receptor expression. J Biol Chem 2001, 276:11387-11392.

12. Dong JW, Albertini F, Nishimori K, Kumar TR, Lu NF, Matzuk MM: Growth differentiation factor-9 is required during early ovarian folliculogenesis. Nature 1996, 383:531-535.

13. Elvin JA, Yan CN, Wang P, Nishimori K, Matzuk MM: Molecular characterization of the follicle defects in the growth differentiation factor 9-deficient ovary. Mol Endo 1999, 13:1018-1034.

14. Yan C, Wang P, DeMayo J, Elvin JA, Carino C, Prasad SV, Skinner SS, Dunbar BS, Dube JL, Celeate AJ, Matzuk MM: Synergistic roles of bone morphogenetic protein 15 and growth differentiation factor 9 in ovarian function. Mol Endocrinol 2001, 15:854-866.

15. Galloway SM, McNatty KP, Cambridge LM, Laitinen MPE, Juengel JL, Jokiranta TS, McLaren RJ, Luiro K, Dodds KG, Montgomery GW, Beattie AE, Davis GH, Ritvos O: Mutation in an oocyte-derived growth factor gene (BMP15) cause increased ovulation rate and infertility in a dosagesensitive manner. Nat Genet 2000, 25:279-283.

16. Hanrahan JP, Gregan SM, Mulsant P, Mullen M, Davis GH, Powell R, Galloway SM: Mutation in the genes for oocyte-derived growth factors GDF9 and BMP15 are associated with both increased ovulation rate and sterility in Cambridge and Belclare sheep (Ovis aries). Biol Reprod 2004, 70:900-909. 
17. Galloway SM, Gregan SM, Wilson KP, McNatty JL, Juengel JL, Ritvos O, Davis GH: Bmp15 mutations and ovarian function. Mol Cell Endo 2002, 191:15-18.

18. Pennetier S, Uzbekova S, Perreau C, Pappillier P, Mermillod P, Dalbies-Tran R: Spatio-temporal expression of the germ cell marker genes MATER, ZAR1, GDF9, BMP15, and VASA in adult bovine tissues, oocyte and preimplantation embryos. Biol Reprod 2004, 71:1359-1366.

19. Hussein TS, Thompson G, Gilchrist RB: Oocyte-secreted factors enhance oocyte developmental competence. Dev Biol 2006, 296:514-521.

20. Hosoe M, Furusawa T, Noguchi J, Tokunaga T: Growth of follicles of various animals following ovarian grafting under the kidney capsules of immunodeficient mice. Reprod Med Biol 2008, 7:45-54.

21. Palma GA, Tortonese DJ, Sinowatz F: Developmental capacity in vitro of prepubertal oocytes. Anat Histol Embryol 2001, 30:295-300.

22. Salamone DF, Damiani P, Fissore RA, Duby RT: Biochemical and developmental evidence that ooplasmic maturation of prepubertal bovine oocytes is compromised. Biol Reprod 2001, 64:1761-1768.

23. Revel F, Mermillod P, Peynot N, Renard JP, Heyman Y: Low developmental capacity of in vitro matured and fertilized oocytes from calves compared with that of cows. J Reprod Fertil 1995, 103:115-120.

24. Khatir H, Lonergan P, Touze $J$, Mermillod P: The characterization of bovine embryos obtained from prepubertal calf oocytes and their viability after non surgical embryo transfer. Theriogenology 1998, 50:1201-1210.

25. Albarracin JL, Morato R, Rojas C, Mogas T: Effects of vitrification in open pulled straws on the cytology of in vitro matured prepubertal and adult bovine oocytes. Theriogenology 2005, 63:890-901.

26. Damiani P, Fissore JB, Cibelli CR, Long CR, Balise JJ, Bobl JM, Duby RT: Evaluation of developmental competence, nuclear and ooplasmic maturation of calf oocytes. Mol Reprod Dev 1996, 45:521-534.

27. Hosoe M, Shioya Y: Distribution of cortical granules in bovine oocytes classfied by cumulus complex. Zygote 1997, 5:371-376.

28. Herath CB, Shiojima S, Ishiwata H, Katsuma S, Kadowaki T, Ushizawa K, Imai K, Takahashi T, Hirasawa A, Tsujimoto G, Hashizume K: Pregnancyassociated changes in genome-wide gene expression profiles in the liver of cow throughout pregnancy. Biochem Biophys Res Commun 2004, 313:666-680

29. Ushizawa K, Takahashi T, Hosoe M, Ishiwata H, Kaneyama K, Kizaki K, Hashizume K: Global gene expression analysis and regulation of the principal genes expressed in bovine placenta in relation to the transcription factor AP-2 family. Reprod Biol Endocrinol 2007, 5:17.

30. Hayashi KG, Ushizawa K, Hosoe M, Takahashi T: Differential genome-wide gene expression profiling of bovine largest and second-largest follicles: identification of genes associated with growth of dominant follicles. Reprod Biol Endocrinol 2010, 8:11.

31. Kizaki K, Yamada O, Nakano H, Takahashi T, Yamauchi N, Imai K, Hashizume K: Cloning and localization of heparanase in bovine placenta. Placenta 2003, 24:424-430.

32. Laemmli UK: Cleavage of structural proteins during the assembly of the head of bacteriophage T4. Nature 1970, 227:680-685.

33. Towbin H, Staehelin T, Gordon J: Electrophoretic transfer of proteins from polyacrylamide gels to nitrocellulose sheets: procedure and some applications. Proc Natl Acad Sci USA 1979, 76:4350-4354.

34. Sendai $Y$, Itoh T, Yamashita S, Hoshi H: Molecular cloning of a encoding a bovine growth differentiation factor-9 (GDF9) and expression of GDF-9 in bovine ovarian oocytes and in vitro-produced embryos. Cloning 2001, 3:3-10.

35. Bodenstainer KJ, Clay CM, Moeller CL, Sawyer HR: Molecular cloning of the ovine growth/differentiation factor-9 gene and expression of growth/ differentiation factor-9 in ovine and bovine ovaries. Biol Reprod 1999, 60:381-386.

36. McNatty KP, Heath DA, Hudson NL, Lun S, Juengel JL, Moore LG: Gonadotriphin-responsiveness of granulosa cells from bone morphogenetic protein 15 heterozygous mutant sheep. Reproduction 2009, 138:545-551.

37. Hayashi M, McGee EA, Min G, Klein C, Rose UM, Duin M, Hsueh AJW: Recombinant growth differentiation factor-9 (GDF-9) enhances growth and differentiation of cultured early ovarian follicles. Endocrinology 1999, 140:1236-1244.
38. Erickson GF, Shimasaki S: The spatiotemporal expression pattern of the bone morphogenetic protein family in rat ovary cell types during the estrous cycle. Reprod Biol Endo 2003, 1:9.

39. Asou S, Anahory T, Pantesco V, Carrour TL, Pellestor F, Klein B, Reyftmann L, Dechaud H, Vos JD, Hamamah S: The human cumulus-oocyte complex gene-expression profile. Hum Reprod 2006, 21:1705-1719.

40. Davis GH, McEwan JC, Fennessy PF, Dodds KG, Farquhar PA: Evidence for the presence a major gene influencing ovulation rate on the $X$ chromosome of sheep. Biol Reprod 1991, 44:620-624.

41. Juengel $J$, Hudson NL, Whiting L, McNatty KP: Effects of immunization against bone morphogenetic protein 15 and growth differentiation factor 9 on ovulation rate, fertilization, and pregnancy in ewes. Biol Reprod 2004, 70:557-561.

42. McNatty KP, Juengel JL, Reader KL, Lun S, Myllymaa S, Lawrence SB, Western A, Meerasahib MF, Mottershead DG, Groome NP, Ritvos O, Laitinen MP: Bone morphogenetic protein 15 and growth differentiation factor 9 co- operate to regulate granulosa cell function in ruminants. Reproduction 2005, 129:481-487.

43. Yoshino O, McMahon HE, Sharma S, Shimasaki S: A unique preovulatory expression pattern plays a key role in the physiological functions of BMP-15 in the mouse. Proc Natl Acad Sci USA 2006, 103:10678-10683.

44. Dube JL, Wang P, Elvin J, Lyons KM, Celeste AJ, Matzuk MM: The bone morphogeneic protein 15 gene is X-linked and expressed in oocyte. $\mathrm{Mol}$ Endocrinol 1998, 12:1809-1817.

45. Otsuka F, Shimasaki A: A novel function of bone morphogenetic protein15 in the pituitary: Selective synthesis and secretion of FSH by gonadotropes. Endocrinology 2002, 143:4938-4941.

46. Fitzpatrik SL, Sindoni DM, Shughrue PJ, Lane MV, Merchenthaler IJ, Frail DE: Expression of growth differentiation factor-9 messenger ribonucleic acid in ovarian and nonovarian rodent and human tissues. Endocrinology 1998, 139:2571-2578

doi:10.1186/1477-7827-9-33

Cite this article as: Hosoe et al:: Quantitative analysis of bone morphogenetic protein 15 (BMP15) and growth differentiation factor 9 (GDF9) gene expression in calf and adult bovine ovaries. Reproductive Biology and Endocrinology 2011 9:33.

\section{Submit your next manuscript to BioMed Central and take full advantage of:}

- Convenient online submission

- Thorough peer review

- No space constraints or color figure charges

- Immediate publication on acceptance

- Inclusion in PubMed, CAS, Scopus and Google Scholar

- Research which is freely available for redistribution

Submit your manuscript at www.biomedcentral.com/submit
C) Biomed Central 